\title{
Efektivitas Pendekatan Komunikatif Terhadap Keterampilan Berbicara Bahasa Jerman Siswa
}

\author{
Nurhaliza' dan Muh. Anwar ${ }^{2}$ \\ Fakultas Bahasa dan Sastra, Universitas Negeri Makassar \\ Email : lizadeu173@gmail.com¹
}

E-ISSN : 2579-4574

P-ISSN : 2549-7359

\begin{abstract}
The purpose of this study was to obtain data related the effectiveness of the communicative approach in increasing students' German speaking skills. This research is a quasi-experimental study. The data obtained were analyzed using the t-test formula. The results of data analysis showed t-count 7.45> t-table 2.002 at the level of $a 0.05$. The results showed that the communicative approach was effective in increasing students' speaking skills.
\end{abstract}

Keywords: Effectiveness, Communicative Approach, Speaking Skills

\section{https://ojs.unm.ac.id/eralingua}

\section{PENDAHULUAN}

Bahasa Jerman merupakan salah satu bahasa asing yang diajarkan di SMA dan difokuskan untuk mengembangkan empat kompetensi berbahasa, yaitu mendengar (Hören), berbicara (Sprechen), membaca (Lesen) dan menulis (Schreiben). Salah satu permasalahan yang ditemukan pada siswa adalah keterampilan berbicara bahasa Jerman masih sangat rendah. Hal ini terlihat dari banyaknya siswa yang malu dan takut untuk maju ke depan kelas, bahkan ada beberapa siswa yang berkeringat, berdiri kaku, serta diam di hadapan teman sekelasnya. Untuk meningkatkan motivasi akademik ataupun prestasi akademik peserta didik, maka dibutuhkan penanganan berupa pendekatan pembelajaran yang tepat sesuai dengan masalah yang dihadapi oleh peserta didik (Romadloni dkk., 2017; Mantasiah \& Yusri, 2018; Qalbi et all., 2017; Yusri et all., 2018).

Pendekatan yang dapat memberikan kebebasan pada siswa untuk mengutarakan pendapat secara lisan serta merangkai sendiri kata-kata yang akan diceritakan kepada teman-temannya. Pendekatan komunikatif merupakan pendekatan yang berlandaskan pada pemikiran bahwa kemampuan menggunakan bahasa dalam berkomunikasi merupakan tujuan yang harus dicapai dalam pembelajaran bahasa. Pendekatan komunikatif merupakan pendekatan yang dilandasi oleh pemikiran bahwa kemampuan menggunakan bahasa dalam berkomunikasi merupakan tujuan yang harus dicapai dalam pembelajaran bahasa. Menurut Djiwandono (2008:28), pendekatan komunikatif adalah kemampuan untuk memahami atau mengungkapkan apa yang sudah atau perlu diungkapkan, dengan menggunakan berbagai unsur bahasa yang terdapat di semua bahasa, dalam memahami ungkapan-ungkapan yang ada secara luwes dan disesuaikan dengan perubahan yang senantiasa timbul, tidak semata-mata berdasarkan nilai-nilai 
konvensional yang sudah baku. Lebih lanjut yang dikemukakan oleh Djumingin (2011:45) pendekatan komunikatif adalah kemampuan berfungsi dalam situasi komunikatif yang sebenarnya dalam suatu transaksi spontan yang melibatkan satu orang atau lebih. Hal senada juga dikemukakan oleh Jufri (2017:11) menyatakan bahwa pendekatan komunikatif adalah satu bentuk kalimat dapat mengungkapkan lebih dari satu makna, dan sebaliknya satu makna dapat diungkapkan melalui lebih dari satu pola kalimat.

Pendekatan komunikatif merupakan pendekatan yang dalam penerapannya memerlukan langkah-langkah agar proses penyajiannya dapat berjalan sebagaimana mestinya. Adapun prosedur penggunaan model pembelajaran pendekatan komunikatif yang digunakan dalam penelitian ini yang dikemukakan oleh K. Johnson dan K. Marrow dalam Jufri (2017: 20) yaitu (1) menentukan tujuan yang bersifat operasional; (2) penyajian materi berdasarkan konteks; (3) practice artinya latihan berbahasa; (4) transfer artinya alih pengetahuan. Pada dasarnya, setiap pendekatan memiliki kelebihan dan kekurangan masing-masing, begitupun dengan pendekatan komunikatif yaitu (1) siswa termotivasi dalam belajar karena pada hari pertama pelajaran, langsung dapat berkomunikasi dengan bahasa Jerman, (dalam batas fungsi, kegiatan berbahasa dan keterampilan tetentu); (2) siswa lancar berkomunikasi, dalam arti menguasai kompetensi garamatikal, sosiolinguistik, wacana dan strategis; (3) suasana kelas hidup dengan aktivitas komunikasi antar pelajar dengan berbagai model interaksi dan tingkat kebebasan yang cukup tinggi, sehingga tidak membosankan;.

\section{METODE PENELITIAN}

Penelitian ini menggunakan dua variabel yaitu variabel bebas $(X)$ dan variabel terikat $(Y)$. Variabel bebas yang dimaksud adalah pendekatan komunikatif dan variabel terikat adalah keterampilan berbicara siswa. Desain penelitian adalah Quasi Eksperimental dengan bentuk nonequivalent control group design. Variabel yang digunakan dalam penelitian ini adalah pendekatan komunikatif sebagai variabel bebas $(X)$ dan keterampilan berbicara sebagai variabel terikat $(Y)$. Pendekatan komunikatif sebagai variabel bebas dalam penelitian adalah suatu pendekatan yang setiap siswa mendapat kesempatan untuk berbicara atau dilakukan uji normalitas dengan menggunakan table Z-score, chi-kuadrat, dan uji homogenitas dengan menggunakan uji $\mathrm{F}$ (Fisher), tetapi sebelum menentukan uji normalitas, uji homogenitas data, maupun uji hipotesis terlebih dahulu tentukan nilai rata-rata (mean), simpangan baku, dan varian.

Populasi dalam penelitian ini adalah siswa kelas XI SMA Negeri 4 Tana Toraja yang terdiri dari empat kelas, dengan jumlah siswa 112 orang. Teknik penentuan sampel yang digunakan pada penelitian ini adalah random sampling. Kelas XI IPA 1 yang berjumlah 30 siswa sebagai kelas eksperimen dan kelas XI IPA 3 yang berjumlah 28 siswa sebagai kelas kontrol. Prosedur pengumpulan data pada penelitian ini ada dua yaitu: tes awal (pre-test) dan tes akhir (post-test).

\section{HASIL DAN PEMBAHASAN}

Pada penelitian ini, pre-test yang diberikan untuk mengetahui kemampuan awal siswa dalam keterampilan berbicara bahasa Jerman siswa menunjukkan bahwa 
kelas eksperimen (XI IPA 1) memeroleh nilai rata-rata (mean) sebesar 55 dengan hasil analisis menunjukkan bahwa 6 siswa (20\%) memeroleh nilai terendah yaitu 42 dan 2 siswa (6,67\%) memeroleh nilai tertinggi yaitu 75, sementara kelas kontrol (XI IPA 3) memeroleh nilai rata-rata (mean) sebesar 46,31 dengan hasil analisis menunjukkan bahwa 5 siswa (7,24\%) memeroleh nilai terendah yaitu 33 dan 2 siswa $(6,89 \%)$ memeroleh nilai tertinggi yaitu 67 . Rendahnya perolehan nilai pada kedua kelas tersebut dikarenakan informasi yang disampaikan kurang komunikatif, beberapa kalimat yang diucapkan terdapat kesalahan, kosata yang digunakan masih sangat kurang, serta masih banyak terdapat kesalahan pada pelafalan dan intonasi sehingga tidak dapat dimengerti.

Hasil nilai pre-tes tersebut kemudian di uji dengan menggunakan uji normalitas dan uji homogenitas. Uji normalitas dimaksudkan untuk mengetahui apakah kedua sampel yang diteliti berdistribusi normal atau tidak, sedangkan uji homogenistas dimaksudkan untuk mengetahui apakah kedua sampel dalam penelitian tersebut homogen atau tidak. Hasil analisis uji normalitas menunjukkan bahwa harga yang diperoleh pada kelas eksperimen (XI IPA 1) dan kelas kontrol (XI IPA 3) masing-masing sebesar -129,14 dan-126,52. Hasil tersebut kemudian dibandingkan dengan tabel chi-kuadrat ( $\mathrm{dk}=5$, taraf signinfikasi 0,05$)$ sebesar 11,07 menunjukkan bahwa $x^{2}$ hitung < $x^{2}$ tabel $(-129,14<11,07)$ dan $(-126,52<$ $11,07)$ begitupun data post-test yang diperoleh pada kedua kelas tersebut masingmasing sebesar -1532,4 dan -1564,147. Hasil tersebut kemudian dikonsultasikan dengan tabel chi-kuadrat ( $\mathrm{dk}=5$, taraf signinfikasi 0,05) sebesar 11,07 menunjukkan bahwa $x^{2}$ hitung $<x^{2}$ tabel $(-1532,4<11,07)$ dan $(-1564,147<11,07)$, sehingga distribusi data pre-test dan post-test dinyatakan normal, artinya tes yang diberikan sesuai dengan kemampuan siswa. Adapun hasil uji homogenitas menunjukkan bahwa nilai Fhitung pada kelas ekperimen dan kontrol adalah 1,11. Hasil tersebut dibandingkan dengan Ftabel ( $d k=5$, taraf signinfikasi 0,05) sebesar 5,050 menunjukkan bahwa Fhitung lebih kecil daripada Ftabel $(1,11<5,050)$. Hal ini berarti. Hal tersebut menunjukkan bahwa kelompok data pada kelas eksperimen dan kontrol dinyatakan homogen.

Selanjutnya kelas eksperimen diberikan perlakukan yang berbeda, yakni diberikan proses pengajaran dengan menggunakan pendekatan komunikatif sedangkan siswa pada kelas kontrol diajar tanpa menggunakan pendekatan komunikatif. Setelah 4 kali pertemuan kedua kelas tersebut kembali diberi tes (posttest) keterampilan berbicara bahasa Jerman, dari hasil post- test pada kelas eksperimen (XI IPA 1) yang diajar dengan menggunakan pendekatan komunikatif mengalami peningkatan nilai yang cukup signifikan. Hal ini dapat dilihat dengan perolehan nilai untuk kelas eksperimen, sebanyak 3 siswa (10\%) yang memeroleh nilai terendah yaitu 58 dan 2 siswa $(6,66 \%)$ yang memeroleh nilai tertinggi yaitu 92 dengan rata-rata 72,3 yang sebelumnya hanya 55. Siswa telah mampu menyampaikan informasi dengan kalimat yang baik, kosakata yang digunakan sudah memadai serta pelafalan dan intonasi yang baik.

Adapun kelas kontrol yang belajar tanpa menggunakan pendekatan komunikatif tidak mengalami peningkatan nilai yang begitu signifikan, perolehan nilai menunjukkan bahwa 5 siswa (17,24\%) yang memeroleh nilai terendah, yaitu 33 
dan hanya 2 siswa $(6,89 \%)$ yang memeroleh nilai tertinggi, yaitu 62 dengan nilai ratarata 55,69. Tidak seperti pada kelas eksperimen, informasi yang disampaikan masih terdapat kesalahan pada kalimat, kosakata yang digunakan cukup memadai serta terdapat beberapa kesalahan pada pelafalan dan intonasi tetapi tidak mempengaruhi pemahaman.

Selanjutnya dilakukan pengujian hipotesis dengan menggunakan uji-t untuk mengetahui hasil akhir dari penelitian ini, yaitu ada tidaknya perbedaan tingkat keterampilan berbicara bahasa Jerman siswa pada hasil post-test kelas eksperimen dan kelas kontrol. Hasil penghitungan tersebut diperoleh data bahwa t-hitung sebesar 7,45. Setelah dibandingkan dengan t-tabel pada taraf signifikansi $5 \%$ $(0,05)$ dan dk 59 sebesar 2,002 maka dapat disimpulkan bahwa t-hitung lebih besar daripada t-tabel, yakni t-hitung $(7,45)>$ t-tabel $(2,002)$. Dengan demikian $\mathrm{H}_{1}$ yang berbunyi: ada perbedaan yang signifikan antara keterampilan berbicara bahasa Jerman siswa kelas XI SMA Negeri 4 Tana Toraja yang diajar dengan menggunakan pendekatan komunikatif dan siswa yang tidak diajar dengan menggunakan pendekatan komunikatif dinyatakan diterima. Sedangkan Ho yang berbunyi: tidak ada perbedaan yang signifikan antara keterampilan berbicara bahasa Jerman siswa kelas XI SMA Negeri 4 Tana Toraja yang diajar dengan menggunakan pendekatan komunikatif dan siswa yang tidak diajar dengan menggunakan pendekatan komunikatif dinyatakan ditolak.

Berdasarkan uraian tersebut dapat disimpulkan bahwa penelitian tentang efektifitas pendekatan komunikatif terhadap keterampilan berbicara bahasa Jerman siswa kelas XI SMA Negeri 4 Tana Toraja dinyatakan berhasil atau efektif digunakan dalam pembelajaran. Temuan penelitian ini didukung oleh teori Jufri (2017:15) yang mengemukakan bahwa dalam kegiatan pendekatan komunikatif masing-masing anggota kelompok mendapatkan kesempatan untuk memberikan konstribusi mereka dan mendengarkan pandangan dan pemikiran anggota yang lain. Pendekatan ini dapat digunakan untuk mengatasi kesenjangan kesempatan antara siswa yang aktif dan pasif.

\section{KESIMPULAN}

Pendekatan komunikatif efektif dalam pembelajaran keterampilan berbicara bahasa Jerman siswa kelas XI SMA Negeri 4 Tana Toraja. Hal ini dibuktikan melalui hasil pengujian hipotesis dengan menggunakan uji t terhadap nilai post-test siswa. Adapun hasil analisis uji-t yaitu, $t_{\text {hitung }}=7,45>t_{\text {tabel }}=2,002$ pada taraf signifikansi 0,05. Pembuktian ini menunjukkan bahwa ada perbedaan yang signifikan penggunaan pendekatan komunikatif dengan pembelajaran konvensional.

\section{DAFTAR PUSTAKA}

Djiwandono, Soenardi. (2008). Tes Bahasa Pengangan Bagi Pengajar Bahasa. Jakarta: PT Indeks.

Djumingin, Sulastriningsih. (2011). Strategi dan aplikasi model pembelajaran inovatif bahasa dan sastra. Makassar: Badan Penerbit Universitas Negeri Makassar. 
Iskandarwassid \& Sunendar, D. (2013). Strategi Pembelajaran Bahasa. Bandung: PT Remaja Rosda Karya.

Jufri, J. (2017). Strategi Pembelajaran Bahasa. Makassar: Penerbit UNM Prof. Dr. Jufri, M. Pd. - Pengutipan Google Scholar (scholar.google.co.id)

Mantasiah, R. (2018, June). Pay It Forward Model in Foreign Language Learning to Increase Student's Self Efficacy and Academic Motivation. In Journal of Physics: Conference Series (Vol. 1028, No. 1, p. 012178). IOP Publishing.

Nurjamal, Daeng. Dkk. (2011). Terampil Berbicara. Bandung:Alfabeta.

Qalbi, U. N., Mantasiah, R., Jufri, J., \& Yusri, Y. (2017). Efektivitas Model Pembelajaran Kooperatif Tipe Teams Games Tournaments dalam Keterampilan Menulis Bahasa Jerman Siswa Kelas XII IPA SMA Negeri 1 Bontonompo Kabupaten Gowa. Indonesian Journal of Educational Studies, 20(1).

Romadloni, A., \& Mantasiah, R. Intercultural approach in foreign language learning to improve students' motivation. Senior Editors, 61.

Sanjaya, Wina. (2014). Strategi Pembelajaran: orientasi standar proses pendidikan. Bandung: Fajar Interpratama Mandiri.

Tarigan, Guntur Henry. (2009). Metodologi Pengajaran Bahasa 1. Bandung: Angkasa

Yaumi, Muhammad. (2013). Prinsip-prinsip Desain Pembelajaran. Jakarta: PT Fajar Interpratama Mandiri.

Yusri, Y., Mantasiah, R., \& Jufri, J. (2018). The Use Of Two Stay Two Stray Model in English Teaching to Increase Student's Learning Outcome. Journal Of Advanced English Studies, 1(1), 39-43. 